\title{
Lesson Study Validation: Model for Social and Natural Sciences Teacher Development in the Implementation of National Curriculum in Muhammadiyah Schools, Indonesia
}

\author{
Sofyan Anif ${ }^{1, *}$, Anam Sutopo ${ }^{2}$, Harun Joko Prayitno ${ }^{3}$ \\ ${ }^{1}$ Department of Biology Education, Faculty of Teacher and Training Education, Universitas Muhammadiyah Surakarta, Indonesia \\ ${ }^{2}$ Department of English Education, Faculty of Trainer and Training Education Universitas Muhammadiyah Surakarta, Indonesia \\ ${ }^{3}$ Department of Indonesian Education, Faculty of Trainer and Training Education Universitas Muhammadiyah Surakarta, Indonesia
}

Received June 29, 2019; Revised September 26, 2019; Accepted November 6, 2019

Copyright $\mathrm{C} 2020$ by authors, all rights reserved. Authors agree that this article remains permanently open access under the terms of the Creative Commons Attribution License 4.0 International License

\begin{abstract}
This study aimed at identifying: 1) the problems faced by Social and natural science teachers of Muhammadiyah Schools Kartasura Indonesia in the implementation of National Curriculum, 2) suitable model for Social and natural science teacher development in the implementation of National Curriculum, 3) lesson study validation as a model for Social and natural science teacher development in the implementation of National Curriculum. Qualitative approach, the paradigm of social definitions particularly on micro studies, was employed in this study. The research subjects were 30 teachers of Muhammadiyah Elementary Schools in Kartasura Indonesia. The informants were teachers, principals, and supervisors. Data collection techniques included documentation, questionnaire, observation, test, and interview. Data analysis techniques were the first and second interpretations. The flow of data analysis included data reduction, data presentation, and conclusion. This study found out: 1) the problems faced by Social and natural science teachers in the implementation of National Curriculum consist of internal and external issues, 2) model for Social and Natural Science teacher development in the implementation of National Curriculum incorporates lesson study approach and collaborative approach, i.e., workshops, laboratory training, and teacher mentoring, 3) lesson study validation as a model for Social and Natural
\end{abstract}

Science teacher development in the implementation of National Curriculum involves validation of theory and practice.

Keywords Validation, Lesson Study, Model, Development, Teacher

\section{Introduction}

The result of survey done by the Directorate of the Educational Human Resource and Education Quality Assurance, Ministry of National Education-Indonesia, shows that the quality of education in Indonesia is still low. It was caused by many factors, one of which is the quality of teachers' competence, which is still low and supported by the number of mismatch teachers in Elementary School. In a sense, teachers in all levels of education in Indonesia have low competence, only dealing with pedagogical competence but also professional one [1]. Moreover, he says that the teachers mismatch average in Indonesia is 36.6 and the highest one teachers of Elementary School. The comprehensive data could be seen in the following table: 
Table 1. The Result of Professional Competence Test 2014

\begin{tabular}{|c|c|c|c|c|c|c|}
\hline No & Subject & Number of items & Average & $\begin{array}{c}\text { Deviation } \\
\text { Standard }\end{array}$ & Low & High \\
\hline 1. & $\begin{array}{c}\text { General Test for } \\
\text { Elementary School/ } \\
\text { Kindergarten }\end{array}$ & 90 & 34,26 & 6,56 & 87 \\
\hline 2. & Teachers of Kindergarten & 80 & 41,95 & 8,62 & 5 & 77 \\
\hline 3. & $\begin{array}{c}\text { Elementary School } \\
\text { Teachers }\end{array}$ & 100 & 37,82 & 8,01 & 86 \\
\hline 4. & $\begin{array}{c}\text { Sport teachers of } \\
\text { Elementary School }\end{array}$ & 40 & 21,88 & 5,56 & 8 & 36 \\
\hline
\end{tabular}

(Source: Directorate of the Educational Human Resource and Education Quality Assurance 2014)

The learning quality in Elementary Schools is highly linked to several factors. Wina suggested that there are three factors contributing to a quality, namely students (raw input), learning facilities (instrumental input), and learning environment (environmental input) [2]. The components of raw input cover student's characteristics including intention, talent, intelligence, and maturity. Instrumental input consists of teachers, objectives, curriculum, modules, methods, approaches, media, evaluation, and other facilities, while environmental input includes building design, location, temperature, family, and community.

The learning quality, however, can be improved through several approaches such as internal, external and cooperative approaches [3]. Internal approach refers to professional teachers as mentors, external approach refers to workshops, training and further study for teachers, while cooperative approach refers to collaboration among teachers of similar subjects, schools, and universities. The development of professional teachers can integrate those approaches through lesson study-based professional teaching development.

Lesson study-based professional teacher development model comprises activities to improve the professional competence of teachers and the quality of learning, as well as to analyze research-based teaching practices. Nevertheless, this model has not been implemented in Indonesia despite of its worldwide popularity and its success in Japan. [4] Subadi, Rita and Sutarni explained lesson study as a method to analyze learning practices conducted in the form of research-based learning for devising specific learning innovation, which includes three stages of planning, learning and observation, and reflection. [5]

Lesson study-based professional teacher development model has been discussed in many studies. Sagor suggested lesson study as a research that involves the main stages of planning, action and reflection.[6] Meanwhile, Richardson suggested seven stages, namely: (1) form a lesson study team, (2) focus the lesson study, (3) plan the study lesson, (4) prepare for the observation, (5) teaching and lesson observation, (6) debriefing the lesson, (7) plan the next steps. [7] Lewis proposed six stages that include: (1) form a lesson study group, (2) focus the lesson study, (3) plan the study lesson, (4) learning in class and observation, (5) reflect the lesson, and (6) plan the next steps [8]

The Third International Mathematics and Science Study (IMSS) explicated lesson study has been used to compare the achievements of Mathematics and Natural Science of primary school students in Japan. Furthermore, 31 countries were involved in TIMSS, and 20 of those countries gained a significantly higher average score of Mathematics than the United States. They included Singapore, Korea, Japan, Canada, France, Australia, and Ireland. Meanwhile, seven countries with significantly lower average score than the United States were Lithuania, Cyprus, Portugal, Iran, Kuwait, Indonesia, Colombia, and Africa. Lesson Study is developed in Indonesia through Indonesia Mathematics and Science Teacher Education Project (IMSTEP) that has been implemented since October 1998 in IKIP Bandung, IKIP Yogyakarta and IKIP Malang, in collaboration with Japan International Cooperation Agency (JICA). It aims to improve the quality of Mathematics and Natural Science education in Indonesia in general and in those IKIPs in particular.

Is lesson study only appropriate for Mathematics and Natural Science teachers? Is lesson study inappropriate for Social Sciences, Language, Economics, and Law teachers? To answer those questions, lesson study-based teacher development model should be developed and tested on teachers with different subjects, except Mathematics and Natural Science.

Roadmap of lesson study as a model of teacher development has been initiated in 2007-2014. Subadi asserted two problems encountered by lecturers in the attempt of quality improvement of lesson study-based General Psychology, namely: 1) lectures' internal problems include their ability to create an active, effective, innovative, creative, and joyful learning, and 2) external problems include any issues related with students, leaders, curriculum, facilities and infrastructure. Subadi emphasized the lesson study conceptual model to improve the quality of modified Classroom Action Research-based teachers. Furthermore, Subadi reasserted the barriers faced 
by teachers of elementary schools in enhancing the lesson study-based learning are linked to teachers' ability: 1) to develop curriculum into quality learning, 2) to develop HOTS (higher cognitive level), 3) to understand micro teaching as in-service training and pre-service training, 4) to understand scientific concept and implementation steps, 5) to recognize lesson study as a training model, as well as students' ability: 1) to interact with students, teachers, materials, and media, and 2) to master the competencies taught by teachers [9]

Furthermore, Subadi confirmed that: 1) the effectiveness of lesson study as a model for improving the competencies of elementary school's teachers is through Principal Working Group in which its implementation is through the Teacher Working Group, 2) assessment of lesson study as a model for improving the quality of elementary school's teachers is done programmatically, on a limited scale, and reflection [10] Subadi also concluded that: 1) assessment of lesson study as teacher training model shall be adjusted to the respective problems and carried out through three stages of socialization of lesson study, workshop and continued implementation in the classroom [11] Some conclusions were also suggested based on Subadi (2012), namely: 1) four issues regarding with the educator's professionalism development, i.e., internal problems, external problems, teacher commitment and willingness, 2) effective lesson study is based on Classroom Action Research (PTK) covering plan-do-see coordinated in Principal Working Group, and implementation of lesson study based on Subject Teacher Working Group [11]. In 2013, Subadi revealed that lesson study-based of professional educator training model is able to solve the educational-related problems in Muhammadiyah School in Sukoharjo Regency.[12] It was specifically applied "modified lesson study, four stages three cycles" (academic study, planning, action and observation, reflection stages, as well as the first, second, and third cycles). Moreover, Subadi affirmed that the implementation of four approaches in lesson study-based teacher development model to elevate professionalism among teachers in Muhammadiyah Schools in Sukoharjo Regency are collaborative, scientific, active, innovative, creative, effective, fun learning, and competence approaches.[13]

This study examines lesson study validation as a model for Social Science teacher development. This study aims at identifying: 1) problems faced by Social and Natural Science teachers in the implementation of National Curriculum, 2) model for Social and Natural Science teacher development in the implementation of National Curriculum, 3) lesson study validation as a model for Social and Natural Science teacher development in the implementation of National Curriculum.

The current Indonesian national curriculum applies scientific approach, which is highly relevant to Bruner's discovery learning theory. There are four main points related to learning theory.[14] First, individuals that learn and develop their minds. Second, knowledge through the discovery process supports learners in gaining intellectual contentment. Third, the technique of discovery will lead students to have opportunity to make the discovery. Fourth, the discovery will strengthen students' memories.

The points above correspond to the cognitive processes required in learning with the scientific approach as proposed by Bloom, which involves observing, questioning, experimenting, associating, and networking.[15] In its implementation, the National Curriculum requires a unity of learning, unanimity of life and real life, which can merely be reflected through integrated learning, e.g., Social Science. [16]

The elementary school teachers involved in this study had not attended any workshop and training on the implementation of National Curriculum, despite the fact that the government through the Minister of Education had instructed its implementation on by the end of 2019. It implies the problems in the Indonesian educational system. First, the fundamental problem, the educational paradigm fails the whole implementation of the educational system. Second, problems resulted from the applied approaches and methods. Third, other problems related to teacher educational system that is less emphasized to mentoring system.

\section{Research Method}

This research employed qualitative descriptive phenomenological approach and micro study of social paradigm. Social paradigm provides opportunity for individual as research subjects to make interpretations. Subsequently, the researchers elaborate those interpretations to obtain relevant scientific knowledge about: 1) identification of problems faced by Social and Natural Science teachers in the implementation of National Curriculum, 2) model for Social and Natural Science professional teacher development in the implementation of National Curriculum, 3) lesson study validation as a model for Social and Natural Science teacher development in the implementation of National Curriculum. Moreover, the modified Classroom Action Research was selected as research design, particularly study on academic, planning, action and observation, and reflection by actors.

The study was conducted at Muhammadiyah Elementary Schools in Kartasura, Central Java Province, Indonesia, namely SD IT, MIM PK, MIM Ganilan, 5 MIM Pucangan, 5 MIM Kertonatan, and MIM Wirogunan. Five teachers were selected from each school hence there was a total of 30 teachers. This study also involved informants, i.e., teachers, principals, and supervisors.

Data collection techniques were questionnaires, observation, test, and interview. Technique of data analysis used flow approach in which data was analyzed since 
lesson activities and developed during learning process until quality learning was obtained. The collected data were analysed by using an Interactive analysis as figured out by Mile.[17] First, data in the form of speeches collected from observation on model teachers and in-depth interview were analyzed. Second, data analysis consists of three activities that occur simultaneously, namely data reduction, data presentation, and conclusion.

\section{Results and Discussion}

1. Problems faced by Social and Natural Science teachers of Muhammadiyah Elementary Schools in Kartasura in the implementation of National Curriculum.

Based on the data collected from questionnaire that was adjusted to the type of activities, problems, problem solving, and complexity levels, with reference to 13 basic competencies: 1) teacher's competency to develop curriculum, 2) teacher's competency to understand the policy and dynamics of curriculum development, 3) teacher's competency to foster character building, 4) teacher's competency to conduct literacy implementation, 5 ) teacher's competency to implement lesson study as a professional teacher development model, 6) teacher's competency to develop Lesson Plans, 7) teacher's competency to develop appraisal instruments, 8) student's ability in active learning, 9) student's ability to master competency taught by teachers, 10) student's ability to develop higher order thinking skills (HOTS), 11) student's ability to analyze and make conclusions, 12) principal's contribution to provide motivation, 13) school supervisor's role in learning process. These components were assessed based on scores: A (very complicated), B (fairly complicated), C (slightly complicated), and D (easy). Subsequently, questionnaires were distributed to respondents.

The results of questionnaire analysis revealed two issues related to the implementation of National Curriculum encountered by Social Science teachers, namely the internal and external problems. Internal problems include: teacher's competency to develop curriculum, teacher's competency to understand the policy and dynamics of curriculum development, teacher's competency to foster character building, teacher's competency to apply literacy implementation, teacher's competency to implement lesson study as a professional teacher development model, teacher's competency to develop Lesson Plans, and teacher's competency to develop appraisal instruments. While, external one may consist of: student's ability in active learning, student's ability to master competency taught by teachers, student's ability to develop higher order thinking skills (HOTS), student's ability to analyze and make conclusions, principal's role to provide motivation, school supervisor's contribution in teaching process.
Subedi [18] stated that problems undergone by Social Science Teachers in the Implementation of National Curriculum reflected the percentages of complexity level which are 1) $17.629 \%$ as very complicated $(58 / 329 \mathrm{x}$ $100 \%), 2) 26.747 \%$, as fairly complicated $(88: 329 \mathrm{x}$ $100 \%), 3) 36.474 \%$ as slightly complicated $(120: 32 \mathrm{x}$ $100 \%)$ and 4) $19.149 \%$ as easy $(63: 329 \times 100 \%)$. The results above confirm the findings suggested by Chokshi in which the implementation of learning shall be equipped with a determined motivation and vision of both students' internal motivation and external motivation from teachers.[19] Nevertheless, problem sourced from students must be addressed immediately to create vivid and fun learning, while problems endured by teachers must be solved at once. Thompson suggested the role of teachers as motivators since they have to: 1) modify learning style into more creative and innovative ones, 2) create breakthroughs for conveying particular Basic Competencies to create class' enthusiasm, and 3) devise modules as reference for students.[20]

\section{Lesson Study-based Professional Development Model for Social and Natural Science Teachers in the Implementation of National Curriculum}

The model for Social and Natural Science teacher development in relation with the implementation of National Curriculum involves a collaborative approach through three main activities: a) workshop, b) laboratory training, and c) model teacher mentoring.

a Workshop was done with the guidance and direction from an expert team. Thirty Social and Natural Science teachers from SD Muhammadiyah Al Kautsar Gompang, MIM PK Kartasura, MIM Ganilan, MIM Pucangan, MIM Kertonatan, and MIM Wirogunan collaboratively discussed the National Curriculum, which covered: (1) curriculum development, (2) policy and dynamics of curriculum development, (3) character building priority, (4) literacy implementation, (5) lesson study as a model of professional teacher development, (6) active learning, (7) learning strategy and lesson plans development, (8) scientific publication writing, (9) appraisal instruments, (10) competencies taught by teachers, (11) quality learning development, (12) peer teaching, (13) model teacher mentoring.

b Laboratory training was done with the guidance and direction from an expert team. Teachers collaborated to devise micro teaching-based lesson plan, micro teaching laboratory-based learning practices (three sessions), and reflection of previous activities.

c Model teacher mentoring stage was divided into several activities, including: 1) teachers formed a lesson study team (each member as a model teacher), 2) each member devised a lesson plan, 3) each member was mentored three sessions while others became observers, and 4) reflection. In this study, 
mentoring model was implemented on model teachers of each lesson study group by using scientific approach with four cycles system, namely academic discussion, learning planning, learning and observation, and reflection as demonstrated in Figure. 1 .

In academic discussion stage, teachers collaborated to examine the syllabus, core competencies (KI), basic competencies (KD), indicators, objectives, models, strategies, methods, media, learning activities, material development, and appraisal instruments. In learning planning stage, teachers collectively devised lesson plan (RPP). In learning and observation stage, teachers implemented lesson study approach in the implementation of National Curriculum assisted by expert team. The steps were: a) introduction (motivation, apperception, and objectives description), b) core activity, which is the implementation of "scientific" approach (observing, questioning, reasoning, trying, networking), c) closing (conclusion, evaluation and assignments, and follow-up). In reflection stage, teachers discussed the implementation of lesson study carried out by model teacher. Furthermore, the results of this discussion are used to improve the preparation and subsequent implementation.

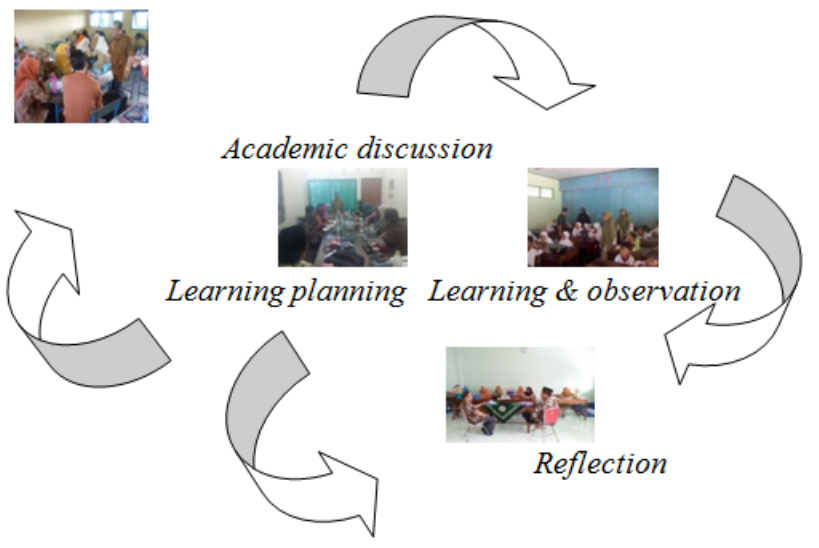

Figure 1. Four cycles system.

The mentoring model applied on Social and Natural Science teachers as explicated above is a "modified lesson study" approach. Such model can improve the learning quality with indicators: a) teachers are capable to collaboratively review National Curriculum, b) teachers are capable to collaboratively devise RPP, teachers are capable to collectively prepare multimedia, d) teachers are capable to collectively plan suitable learning strategies, e) teachers are capable to collectively plan and implement scientific approach, f) teachers are capable to collaboratively provide assessment by recognizing the characteristics of complete, authentic, and continued learning.

Discussion of Social and Natural Science teacher development model in the implementation of National Curriculum uses modified lesson study-based model with collaborative approach, namely workshop, laboratory training, and mentoring model. Mentoring model with lesson study approach was divided into three sessions. It used scientific approach using four cycles system, i.e., academic discussion, learning planning, learning and observation, and reflection. Meanwhile, the mentoring model was designed based on modified lesson study approach.

The findings of this study are in accordance with a lesson study developed in Japan.[21] It involves three main activities of: (1) planning, (2) action and observation, and (3) reflection. Similarly, McTaggart [22] and Kemmis and McTaggart [22] reasserted that lesson study is teacher development model implemented through the cycle-by-cycle system. The first cycle is commenced with: (a) initial reflection to define specific thematic concern, (b) planning, (c) action and observation, and (d) reflection. The second cycle includes: 1) planning revision based on the first cycle reflection, (2) implementation subsequent action and observation, and (3) subsequent reflection. It is associated with the mentoring model with modified lesson study approach. Stewart in a study entitled " $A$ Model for Teacher Collaboration" summarized that the best way to encourage positive improvement at every grade level in a school is by adopting a model.[23]

\section{Lesson Study Validation as Social and Natural Science Teacher Development Model in the Implementation of National Curriculum at Muhammadiyah Elementary School Kartasura}

In this present study, lesson study validation involved: a) validation of academic administration that was based on the quality of lesson plan, b) validation of concepts that was based on the effectiveness of the Modified Action Research Class-based lesson study model, c) validation of learning activities that was based on cycle-based innovative learning model, d) expert validation that was based on experts' assessment.

In-depth interviews with some experts were also conducted. Informant $\mathrm{S}$ affirmed that the test of lesson study validation compares the validated concepts with other verified concepts. Slamet HW suggested modified lesson study developed in this study has succeeded in improving the learning quality and student achievement. Furthermore, Dahroni stated this model has passed the feasibility test in terms of theory and practice.

A participant of workshop, Mulyono, testified "I have attended three sessions of teacher mentoring, which are exceptionally useful for teachers in order to control students during the active and creative learning process, motivate teachers with colleagues as observers, provide discussion with experts, and know the drawbacks and their solutions." Overall, this process can improve students' achievement.

It confirms Andang (Elementary School Supervisor of Karanganyar Regency) in which theoretically, lesson study-based model has many benefits hence it is essential 
to modify the concept, particularly the steps/cycles, from the three stages (planning, action and reflection) into four stages of: (1) exploration (prior the development of lesson plan, a study of syllabus, SK, KD, and indicators to be developed into objectives is required), (2) planning, (3) action, and (4) reflection. The Head of MGMP SD Kodya Surakarta, Narendra, explained lesson study as a fairly effective approach for Social Science teachers since it has been tested and scientifically validated; yet the implementation required modification and socialization through workshop and training.

The lesson study validation, DGSE [24] explained that that the best way to encourage positive improvement at every grade level in a school is by adopting a validated model. Robinson also emphasized learning mathematics with lesson study approach and teacher collaboration evidently supports the relationship between theory and practice.[25]

\section{Conclusions}

Problems faced by Social and Natural Science teachers in the implementation of National Curriculum consist of internal and external problems. The complexity levels of those problems are very complicated (17.629\%), fairly complicated $(26.747 \%)$, slightly complicated $(36.474 \%)$, and easy (19.148\%).

Professional development model for Social and Natural Science teachers in the implementation of National Curriculum uses collaborative approach through three main activities workshop, laboratory training, and mentoring. Mentoring model with lesson study approach is done three sessions that involve scientific approach with four cycles system, i.e., academic discussion, learning planning, learning and observation, and reflection.

This model is based on modified lesson study. It potentially improves the learning quality with indicators: a) teachers are capable to collaboratively review National Curriculum, b) teachers are capable to collaboratively devise RPP, c) teachers are capable to collectively prepare multimedia, d) teachers are capable to collectively plan suitable learning strategies, e) teachers are capable to collectively plan and implement scientific approach, f) teachers are capable to collaboratively provide assessment by recognizing the characteristics of complete, authentic, and continuous learning.

As a model of professional teacher development, lesson study validation consists of four steps, they are : first, academic administration validation based on the quality of lesson plan; second, concept validation based on the effectiveness of the Modified Action Research Class-based lesson study model; third, learning activities validation based on cycle-based innovative learning model, and fourth, expert validation.

\section{Acknowledgements}

The authors thank the Directorate of Research and Community Service, Directorate General of Research and Development, Ministry of Research, Technology, and Higher Education, under the Higher Education Research Grant of the 2017 budget based on research contract No. 211.75/A.3-III/LPPM/V/2017.

\section{REFERENCES}

[1] Baidowi, "Kajian Implementasi Sertifikasi Guru dalam Jabatan". Jakarta: PMPTK Kemdikbud Republik Indonesia, 2009.

[2] Wina, "Pengaruh Sarana Belajar Terhadap Prestasi Belajar Ilmu Pengetahuan Sosial di Sekolah Dasar". Journal Cakrawala Pendas Vol. 2 No. 2 Edisi Juli 2016. ISSN: 2442-7470. 2006.

[3] Subadi. "Metode Penelitian Kualitatif." Surakarta: Muhammadiyah University Press. 2017.

[4] Samino. "Pengembangan Model Peningkatan Kualitas Guru Melalui Pelatihan Lesson Study bagi Guru SD Se-Eks Karesidenan Surakarta". The first year post-graduate grant report, 2009.

[5] Rita, Sutarni, Subadi. "A Lesson Study as a Development Model of Professional Teachers" (Macrothink Institute Journal International of Education). ISSN 1948-5476. Vol. 5, No. 22013, 2013.

[6] Sagor. "How to Conduct Collaborative Action Research" Association for Supervision and Curriculum Development, Alexandria. 1992.

[7] Richardson. "Lesson Study: Teacher Learn How to Improve Instruction". National Staff Development Council. 2006.

[8] Lewis, Catherine C. "Lesson study: A Handbook of Teacher-Led Instructional Change". Philadelphia, PA: Research for Better Schools, Inc. 2002.

[9] Subadi. 'Model Peningkatan Kualitas Guru Melalui Pelatihan Lesson Study bagi Guru SD Se-Eks Karesidenan Surakarta Tahun ke 2" Research Report. Katalog Perpustakaan Pusat dan Publikasi Ilmiah. Universitas Muhammadiyah Surakarta. 2010.

[10] Subadi. "Model Peningkatan Kualitas Guru Melalui Pelatihan Lesson Study bagi Guru SD Se-Eks Karesidenan Surakarta Tahun ke 3". Research Report. Katalog Perpustakaan Pusat dan Publikasi Ilmiah. Universitas Muhammadiyah Surakarta. 2011.

[11] Subadi. "Model Pembinaan Pendidik Profesional dengan Pendekatan Lesson Study pada Guru-Guru Sekolah Muhammadiyah Kabupaten Sukoharjo Tahun ke 1". Research Report. Katalog Perpustakaan Pusat dan Publikasi Ilmiah. Universitas Muhammadiyah Surakarta. 2012.

[12] Subadi. "Model Pembinaan Pendidik Profesional dengan Pendekatan Lesson Study pada Guru-Guru Sekolah 
Muhammadiyah Kabupaten Sukoharjo Tahun ke 2." Research Report. Katalog Perpustakaan Pusat dan Publikasi Ilmiah. Universitas Muhammadiyah Surakarta. 2013.

[13] Subadi. "Model Pembinaan Pendidik Profesional dengan Pendekatan Lesson Study pada Guru-Guru Sekolah Muhammadiyah Kabupaten Sukoharjo Tahun ke 3". Research Report. Katalog Perpustakaan Pusat dan Publikasi Ilmiah. Universitas Muhammadiyah Surakarta. 2014.

[14] Carin, A.A., and Sund, R.B. "Teaching Science Trough Discovery, $3^{\text {rd }}$ Ed." Columbus: Charles E. Merrill Publishing Company. 1975.

[15] Bloom. "Taxonomy of Educational Objectives Handbook 1 Cognitive Domain”. Longman: New York. 1984.

[16] Nasar. "Merancang Pembelajaran Aktif dan Konstektual Berdasarkan "SISCO"2006". Jakarta: PT Gramedia Widiaksara. 2006.

[17] Miles, B.M., and Michael, H. "Qualitative Data Analysis". Jakarta: UI Press.

[18] Subedi, B. and Daza, S.L. (2008). The possibilities of postcolonial praxis in education. Race ethnicity and education, 11(1), 1-10. 2008.

[19] Chokshi. "Phi Delta Kappan,” Bloomington: May 2005. Vol. 86. 2005.

[20] Thompson, "Science Activities", Washington: Winter 2007. Vol. 43. 2007.

[21] Saito. "Development of school based in-service teacher training under the Indonesian Mathematics and Science Teacher Education Project" Improving Schools. Vol.9, 2006.

[22] Kemmis, S \& McTaggart, R. The Action Research Planner. Third Edition. Victoria: Deakin University Press. 2014.

[23] Stewart. 2005. Phi Delta Kappan, Bloomington: May Vol. 86. Iss. 9, pg.681, 7 pgs. 2005.

[24] DGSE., 2002, Report on Validation and Socialization of the Guideline of Syllabi and Evaluation System of Competent-Based Curriculum for Mathematics in Manado, North Sulawesi. Jakarta: Depdiknas.

[25] Robinson. "Lesson Study: An example of its adaptation to Israeli Middle School Teachers.” 2006. 